\title{
Determining the Relative Age of Fault Activity through Analyses of Gouge Mineralogy and Geochemistry: A Case Study from Vápenná (Rychleby Mts), Czech Republic
}

\author{
Lucie Nováková, Pavel Hájek, Martin Št’astný \\ Institute of Rock Structure and Mechanics, Academy of Sciences, v.v.i., Prague, Czech Republic \\ E-mail: lucie.novakova@irsm.cas.cz \\ Received June 1, 2010; revised June 29, 2010; accepted July 16, 2010
}

\begin{abstract}
The relative age of fractures can be determined through structural analyses in the field or through the detailed mineralogical (XRD) and chemical analyses (AAS method, volumetric, and gravimetric analysis) of fault gouge in the laboratory. The aim of this work was to compare these approaches. It was hypothesised that the two methods would yield consistent results. The studied faults were located in the Rychleby Mts, part of the Sudetic Marginal Fault Zone. The relative age of the faults was determined in the field through the application of the intersection law. The fault gouges were sampled in a crystalline limestone quarry near the village of Vápenná. The mineralogical composition of the fault gouges has been established by XRD analysis of powder samples and analysis of preferentially oriented clay minerals. From our result, it is clear that these two approaches yielded consistent results with regard to the relative age of the faults.
\end{abstract}

Keywords: Crystalline Limestone, Intersecting Faults, Fault Gouge, Relative Chronology

\section{Introduction}

The study of brittle tectonics incorporates a wide range of discontinuities from the micro-scale (e.g. cracks and joints) to the mega-scale (e.g. fault zones). Elucidating the relative age of intersecting fractures is a fundamental part of structural geology. However, the technique is rarely described in depth. Hancock [1] demonstrated that it is possible to determine the relative age of fault and joint sets. Groshong [2] described the intersection of faults as sequential or contemporaneous. Sequential faulting defines an older fault that is cut and displaced by a younger fault. Jeong and Cheong [3] provided direct evidence for multiple fault movements through an investigation of the mineralogy, micromorphology, and chemistry of fault gouge.

Fault gouge is a fine-grained breccia formed by the crushing of rocks and minerals. This crushing is induced by fracturing and frictional sliding during fault movements [4]. The constituents of gouge are assumed to be derived from materials in the hanging wall and footwall blocks. The mineralogy and chemistry, however, suggests a quite different origin [3]. From chemical and $\mathrm{X}$-ray analysis, it is seen that clay gouge has a polymineral composition. The main constituents of gouge are quartz, illite, and kaolinite. In addition, also recognised are small amounts of chlorite, smectite, mixed layer illite-smectite, and gypsum [5-8].

The aim of this study is to undertake field investigations and laboratory analyses in order to test these two underlying methods. It is hypothesised that the chemical and X-ray analyses will yield results that are consistent with the classical structural interpretation.

\section{Geological Situation}

The Rychleby Mts are situated in the northeastern part of the Bohemian Massif (Czech Republic) along its border with Poland (Figure 1). The area is characterised by several significant geological boundaries, such as the Ramzová and Nýznerov overthrusts. These overthrusts are usually assumed to mark the contact between the Lugicum and Silezicum domains [9]. To the east, the area is bordered by the important Sudetic Marginal Fault Zone (SMFZ). This zone, which extends for $250 \mathrm{~km}$, has been investigated in detail by many authors [10-14]. It originates in Poland before passing into the Czech Republic. Here, the fault lies close to the towns of Javorník and Jeseník. It terminates on the marginal Jeseník Fault near the town of Opava [15]. Near the village of Váp- 
enná, the Sudetic Marginal Fault separates the crystalline limestones of the Branná group from the Žulová granite pluton.

The crystalline limestones close to Vápenná are of Devonian age. In the bedrock are quartzites and phyllites $[16,17]$. The predominant mineral is usually calcite but locally may be graphite. In addition, also identified are flogopite, muscovite, chlorite, grains of pyrite, and pyrolusite with goethite. Within the crystalline limestones there are smaller veins of an ochre calcite coloured by iron oxides and hydroxides [18]. About $15 \mathrm{~km}$ to the south, hydrothermal copper mineralization has been described in detail at Horní Lipová [19]. About $10 \mathrm{~km}$ to the northeast, an occurrence of contact minerals was described in the Žulová granite pluton at Vycpálek Quarry. These minerals were formed at the contact of the crystalline limestones and the Žulová granite pluton [20]. The association of minerals between adjacent rock formations represents a probable source for the mineral composition within the fault gouges. There is a simple quartzite mineralisation comprising quartz and, predominately, sericite-muscovite but also with sporadic biotite. Another association is comprised of phyllites with smaller layers of green schists and metamorphosed fine-grained diabase tuffs [17].

\section{Methodology}

Two fault planes were chosen as the basis for this methodological case study. These faults represent the main fracture orientations in the area, namely the Sudetic (NW-SE) and the Moravo-Silesian (NE-SW) (Nováková, 2008). Figure 2 shows that Fault A, orientated in the Moravo-Silesian direction, is offset by about $22 \mathrm{~cm}$ along Fault B, in the Sudetic direction. Fault A strikes

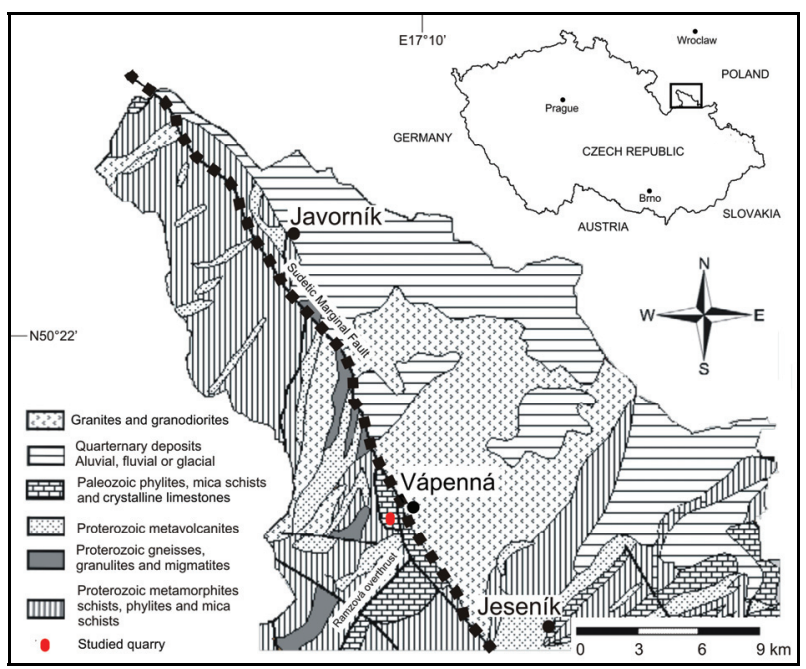

Figure 1. A simplified geological map of the study area in the northeastern part of the Bohemian Massif, Czech Republic (modified after Nováková, 2009). $296^{\circ}$ and dips $66^{\circ}$, whereas Fault B strikes $65^{\circ}$ and dips $31^{\circ}$.

The XRD method is based on the interaction between the sample and X-radiation. It is a very accurate method and produces high quality results for all types of samples. The mineralogical composition of the fault gouges was determined through the diffraction analysis of samples with randomly orientated particles in addition to the analysis of samples with preferentially orientated particles. The samples were suspended in solution and allowed to settle on the glass slide. A Philips PW 7310 $\mathrm{X}$-ray difractograph was set to $\mathrm{CuK} \alpha$ emission, voltage $40 \mathrm{kV}$, current $40 \mathrm{~mA}$, scanning speed $1^{\circ} \mathrm{min}^{-1}$ spreading between 3 to $70^{\circ} 2 \theta$ for randomly orientated samples (Figure 3) and 3 to $35^{\circ} 2 \theta$ for preferentially orientated samples (Figure 4). The obtained X-ray data were interpreted in accordance with Micheev [21] and Swarthmore [22]. The chemical analyses of the samples were undertaken using the AAS method, volumetric, and gravimetric analysis.

\section{Results}

The relative age of the faults was determined during field investigations. Fault A is cut and displaced along Fault B and therefore, according to the intersection law [2], Fault A is older than Fault B. The gouge from Fault A contains crushed carbonates and carbonated breccias of up to 2 $\mathrm{cm}$ surrounded by clay-sand matrix. When the larger debris was inspected it was possible to find tiny amounts of muscovite and chlorite, or crystals of calcite with iron oxides, hydroxides, and quartz. In addition, feldspars and plagioclases are occasionally present. The gouge from Fault B contains carbonate debris and breccias with insipid crystals and a higher proportion of clay matrix. The debris is smaller than about $1 \mathrm{~cm}$. Table 1 and $\mathbf{2}$ present

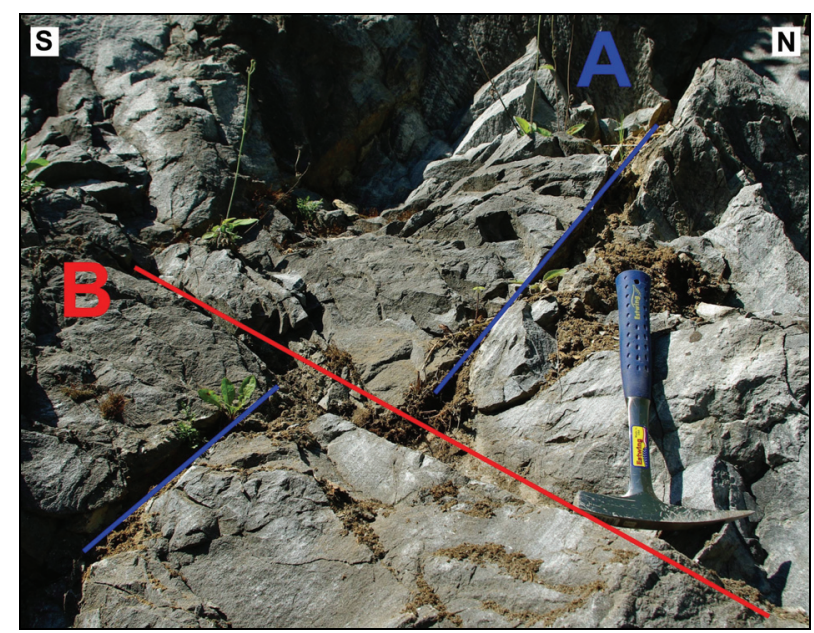

Figure 2. The studied faults: the older fault (Fault A) is intersected and displaced along the younger fault (Fault B). The offset is about $22 \mathrm{~cm}$. 


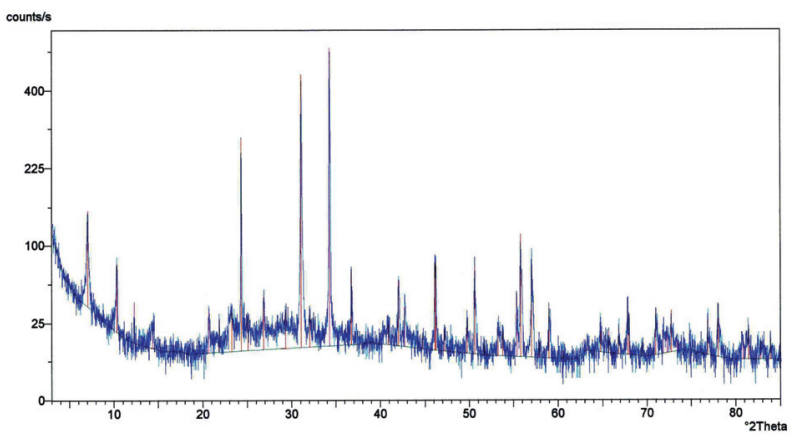

Figure 3. An example (sample A) of the X-ray diffraction curve for randomly orientated samples (for an angle $2 \theta$, it is possible to measure between $0^{\circ}$ and $90^{\circ}$ ).

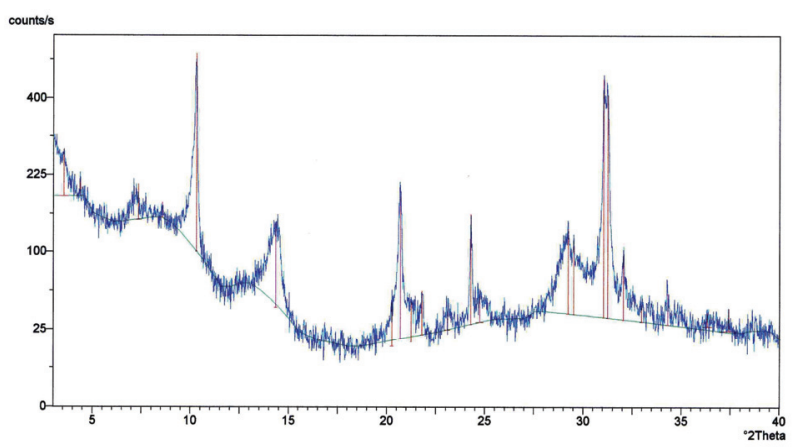

Figure 4. An example (sample A) of the X-ray diffraction curve for preferentially orientated samples (for an angle $2 \theta$, it is possible to measure between $0^{\circ}$ and $40^{\circ}$ ).

the results of X-ray diffraction and chemical analysis respectively.

The colour of both fault gouges is grey to ochre. The gouge from Fault B contains a huge mass of clay minerals with grains smaller than $0.004 \mathrm{~mm}$. Most of the clay is either smectite (up to $60 \%$ ) or illite (up to $22 \%$ ). The proximal surrounding basic rocks are the obvious source of the minerals. In addition, the clay matrix also contains small amount of kaolinite, quartz, K-feldspar, amphibole, and chrome-chlorite (Table 2). Chemically, the gouge consists primarily of $\mathrm{SiO}_{2}, \mathrm{TiO}_{2}$ and iron. The results of the both analyses point to a significant input into the gouge from more distal rocks such as quartzites, phyllites, and green schists.

The gouge from Fault $\mathrm{A}$ is more ochre than that observed in Fault B. The clay matrix is formed predominately of illite, kaolinite, and quartz. Smectite and feldspars are present but less important. In addition, there are minor amounts of calcite, amphibole, and goethite. The chemistry is dominated by $\mathrm{CaO}$. The crushed limestones and calcites in the sample demonstrate the importance of the proximal surrounding crystalline limestones. However, the sample may also be partly derived from more distal rocks. As more stable minerals are found in sample $\mathrm{A}$, it is possible to suggest that the gouge in Fault A is older than the gouge in Fault B. This proposal is in agreement with the previous observations of Skácel [11].

\section{Discussion and Conclusions}

The intersecting faults, A and B on Figure 2, were located in a quarry close to the village of Vápenná. These faults follow regionally important orientations. Field observations allowed a relative fault chronology to be proposed. Fault A is cut and displaced along Fault B and therefore, according to the intersection law, Fault A is older than Fault B. From this, it is possible to suggest that the last movement along the Sudetic fault plane occurred after the last movement along the Moravo-Silesian fault plane. The fault gouges were studied from both a mineralogical and chemical perspective.

These characteristics of the gouges corroborate the field observations. Fault A contains crushed calcite and this fault was later sealed by recrystallised calcite. Reactivation of this calcite vein led to the formation of the calcite powder seen at the base of the gouge in Fault A. This fault has subsequently been cut by Fault B. The strong influence of more distal (i.e., non-limestone) rocks in the gouge is predominately represented by $\mathrm{SiO}_{2}$.

Despite the small number of studied faults, both the field investigation and laboratory analyses yield consis-

Table 1. The results of the $\mathrm{X}$-ray diffraction of the fault gouges (qualitative analysis and semi-quantitative estimate of content of minerals).

\begin{tabular}{lcccccccccc}
\hline & \multicolumn{11}{c}{ Minerals [\%] } \\
\hline Samples & $S$ & $C h$ & $I$ & $K$ & $Q$ & $K f$ & $P l g$ & $A m$ & $G e$ & $C a$ \\
A-random sample & 12 & - & 6 & 1 & 22 & 2 & - & 3 & 2 & 52 \\
A-oriented sample & 7 & 6 & 43 & 10 & 20 & 7 & - & 2 & 2 & 3 \\
B-random sample & 12 & - & 10 & 2 & 41 & 7 & 1 & - & - & 27 \\
B-oriented sample & 60 & 4 & 22 & 7 & 4 & 1 & - & 2 & - & - \\
\hline
\end{tabular}

Table 2. The results of the chemical analysis of the fault gouges.

\begin{tabular}{|c|c|c|}
\hline & Sample A [\%] & Sample B [\%] \\
\hline $\mathrm{SiO}_{2}$ & 23,86 & 59,99 \\
\hline $\mathrm{TiO}_{2}$ & 0,46 & 0,84 \\
\hline $\mathrm{Al}_{2} \mathrm{O}_{3}$ & 9,49 & 9,46 \\
\hline $\mathrm{Fe}_{2} \mathrm{O}_{3}$ & 4,43 & 4,72 \\
\hline $\mathrm{FeO}$ & 0,14 & 0,55 \\
\hline $\mathrm{MnO}$ & 0,091 & 0,134 \\
\hline $\mathrm{MgO}$ & 1,33 & 1,68 \\
\hline $\mathrm{CaO}$ & 29,78 & 7,79 \\
\hline $\mathrm{Na}_{2} \mathrm{O}$ & 0,05 & 0,08 \\
\hline $\mathrm{K}_{2} \mathrm{O}$ & 1,27 & 2,1 \\
\hline $\mathrm{P}_{2} \mathrm{O}_{5}$ & 0,12 & 0,18 \\
\hline$-\mathrm{H}_{2} \mathrm{O}$ & 1,88 & 1,80 \\
\hline Ignition loss & 28,66 & 12,14 \\
\hline $\mathrm{Cr}$ & $66\left[\mathrm{mg} \cdot \mathrm{kg}^{-1}\right]$ & $94\left[\mathrm{mg} \cdot \mathrm{kg}^{-1}\right]$ \\
\hline
\end{tabular}


tent results regarding the relative age of the faults. These indicate that Fault A is older than Fault B. It is considered that this combined approach promises to provide new opportunities in the study of relative fault chronologies. Moreover, this study suggests that robust results may be obtained through X-ray and chemical analyses in places where it has hitherto not been possible to determine the relative age of the faults through detailed structural investigations.

\section{Acknowledgements}

The research was funded by the Grant Agency of Charles University (43-258020), the Institute of Rock Structure and Mechanics AS CR, v.v.i. (A VOZ30460519), the Ministry of Education, Youth and Sports (LC506) and the Czech Science Foundation (250/09/1244). We are grateful to the reviewer for the constructive review and to our colleagues and friends for useful discussions, advances and technical support. M. D. Rowberry provided a critical revision of the English.

\section{References}

[1] P. L. Hancock, "Brittle Microtectonics: Principles and Practise," Journal of Structural Geology, Vol. 12, No. 7, 1985, pp. 437-457.

[2] G. H. Groshong, "3-D Structural Geology A Practical Guide to Quantitative Surface and Subsurface Map Interpretation," 2nd Edition, Springer, The Netherlands, 2006.

[3] G. Y. Jeong and C. S. Cheong, "Recurrent Events on a Quaternary Fault Recorded in the Mineralogy and Micromorphology of a Weathering Profile, Yangsan Fault System, Korea," Quaternary Research, Vol. 64, No. 2, 2005, pp. 221-233.

[4] G. H. Davis and S. J. Reynolds, "Structural Geology of Rocks and Regions," John Wiley and Sons, New York, 1996.

[5] H. Zwingmann and N. Mancktelow, "Timing of Alpine Fault Gouges," Earth and Planetary Science Letters, Vol. 223, No. 3-4, 2004, pp. 415-425.

[6] P. Hájek and M. Št'astný, "Mineralogy of the Clay Gouge on Prague Fault," Acta Geodynamica et Geomaterialia, Vol. 4, No. 3(147), 2007, pp. 33-37.

[7] M. J. Ikari, D. M. Saffer and C. Marone, "Frictional and Hydrologic Properties of Clay-Rich Fault Gouge," Journal of Geophysical Research - Solid Earth, Vol. 114, No. B05409, 2009.

[8] R. Offler, D. J. Och, D. Phelan and H. Zwingmann, "Mineralogy of Gouge in North-Northeast-Striking Faults, Sydney Region, New South Wales," Australian Journal of Earth Sciences, Vol. 56, No. 7, 2009, pp. 889-905.
[9] M. Opletal and V. Pecina, "The Ramzová Tectonic Zone: The Contact between Lugicum and Silesicum," Acta Geodynamica et Geomaterialia, Vol. 1, No. 3(135), 2004, pp. 41-47.

[10] J. Badura, W. Zuchiewicz and B. Przybylski, "The Sudetic Marginal fault, SW Poland: A Reactivated Sinistral-Normal Fault," Geolines, Vol. 17, No. 1, 2004, pp. 17-18.

[11] J. Skácel, “The Sudetic Marginal Fault between Bílá Voda and Lipová Lázně," Acta Geodynamica et Geomaterialia, Vol. 1, No. 3(135), 2004, pp. 31-33.

[12] L. Nováková, "Main Directions of the Fractures in the Limestone and Granite Quarries along the Sudetic Marginal fault near Vápenná village, NE Bohemian Massif, Czech Republic," Acta Geodynamica et Geomaterialia, Vol. 5, No. 1(149), 2008, pp. 49-55.

[13] P. Štěpančíková, J. Stemberk, V. Vilímek and B. Košt’ák, "Neotectonic Development of Drainage Network in the East Sudeten Mountains and Monitoring of Recent Fault Displacements (Czech Republic)," Special Issue on: Impact of Active Tectonics and Uplift on Fluvial Landscapes and Rift Halley Development, Geomorphology, Vol. 102, No. 1, 2008, pp. 68-80.

[14] L. Nováková, "Detailed Brittle Tectonic Analysis of the Limestones in the Quarries near Vápenná Village," Acta Geodynamica et Geomaterialia, Vol. 7, No. 2(158), 2010, pp. 1-8.

[15] T. Buday, D. Ďurica, M. Opletal and J. Šebesta, "Significance of the Bělský and Klepáčovský Fault System and its Continuation to the Carpathian Mts," Uhli, Rudy, Geologický Průzkum (in Czech), Vol. 2, No. 9, 1995, pp. 275-281.

[16] L. Nováková, "Brittle Tectonic Investigations in the North-Eastern Part of the Bohemian Massif, Czech Republic," 71st EAGE Annual Conference and Exhibition in Amsterdam, June 2009.

[17] Z. Mísař and J. Skácel, "Devonian of Upper Part of the Branná Group," In: Pouba, et al., Eds., Legend to the Geological Map of ČSSR 1:200000 (in Czech), Nakladatelství ČS AV, 1978.

[18] J. Zimák and J. Śtelcl, "Natural Radioactivity of the Rocks in the Cave Na Pomezí near Jeseník," Geologický výzkum Moravy a Slezska v r. 2003, 2004, pp. 107-108.

[19] Z. Dolníček, B. Fojt, M. Nekejchal, R. Škoda and V. Vávra, "New Discovery of Mineralization in the $\mathrm{Na}$ Pomezí Quarry (Horní Lipová)," Sbornik Abstrakti̊ Semináre Moravoslezského paleozoika, Brno, 2006.

[20] Z. Losos and M. Brož, "Paragenesis a Chemism of Bimetasomatic Contact Zones of Žulová Massif," Mineralogie ČM a ZK (in Czech), Vol. 1, 2002, pp. 59-63.

[21] V. I. Micheejev, "X-Ray Determination of the Minerals," Nauka Moskva (in Russian), 1957, p. 867.

[22] P. A. Swarthmore, "Mineral Powder Diffraction File Data Book JCPDS," American Ceramic Society, 1980. 